\title{
The Role of the Library in the First College Year: The Canadian Perspective
}

\section{Ursula Trescases}

Ryerson University

digital.library.ryerson.ca/object/186

Please Cite:

Trescases, U. (2008), The role of the library in the first college year: The Canadian perspective. Reference Services Review, 36(3), 301-311. $\underline{\text { doi: } 10.1108 / 00907320810895387}$

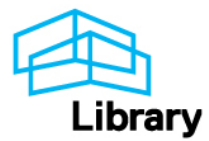




\title{
The role of the library in the first college year: the Canadian perspective
}

\author{
Ursula Trescases \\ Ryerson University Library, Toronto, Ontario, Canada
}

\begin{abstract}
Purpose - The aims of this paper is to provide an overview on information literacy/library programs for first-year students in Canadian universities and colleges.

Design/methodology/approach - The paper introduces and discusses periodical articles, monographs and up-to-date research on the subject. It presents anecdotal evidence gained from web site searches of 169 Canadian post-secondary institutions complemented by personal communications from library and student services staff.

Findings - The study provides information about several types of library services for first-year students currently in use in Canadian academic libraries.

Originality/value - There is no evidence of research in the area of library services for first-year college and university students in Canada. This paper complements research on information literacy/library programs offered through academic libraries in other countries by focusing solely on first-year student initiatives in Canadian academic libraries.
\end{abstract}

Keyword(s): Information literacy; Academic libraries; Students; Canada.

Reference Services Review, 36 (3): 301-311, 2008

\section{Introduction}

There is a substantial body of literature, mostly from American sources, on first-year experience initiatives involving academic libraries. The most recent publication on this topic, The Role of the Library in the First College Year (Hardesty, 2007), a monograph with contributions from eminent scholars and librarians, provides extensive and up-to-date information on library instruction during the first year of college in post-secondary institutions in the USA only. As far as the author was able to ascertain, to date, there is a distinct paucity of articles that specifically address the Canadian aspect. The only significant studies related to academic libraries in Canada examine information literacy instruction to all students and do not emphasize services for firstyear students (Julien, 2005; Julien and Boon, 2003, 2004).

This paper reviews literature on library services for first-year students enrolled in Canadian universities and colleges and presents new findings gained from sources that include information posted in web sites and personal communications from academic librarians and student services staff at Canadian post-secondary institutions. It is based on a report prepared by the author in response to the reports by the Task Force on Student Success and Retention (Britnell et al., 2002) and its subgroup, the University 101 Task Force (Kinder et al., 2006), at Ryerson University, which identified and developed strategies to improve the level of student academic success and made recommendations for best practices. Given that information literacy and research skills 
rank high on the list of recommendations, the author was asked to examine the role academic libraries assume within the context of the first-year experience.

\section{The first-year experience}

The term "first-year experience" came into vogue in the early 1970s at a time of student unrests in university and college campuses in the USA which was caused, among others, by political and educational factors. The character of the traditional student population had changed dramatically from mostly white, male, affluent, and Protestant students to include members from the opposite sex, minority groups, different religious groups, and members from middle class and lower income families. High drop-out rates during the first year of college were a cause of concern and gave rise to discussions on student retention. It is important to note that, aside from the structure of instruction and other academic and non-academic reasons, "Insufficient exposure to or use of the library" was cited as one of the major causes responsible for the failure of first year students (Chapman et al., 1997, p. 6). Indeed, library instruction became part, in varying formats, of firstyear seminars or University 101 type seminars introduced in a large number of post-secondary educational institutions in the USA, subsequent to the national and international conferences organized by the University of South Carolina since 1982. These seminars basically followed the University 101 model of the University of South Carolina, where it had been offered since 1972.

The first-year experience at Canadian colleges and universities followed a different path. While the history of post-secondary education and student characteristics in Canada are comparable to those in the USA, a significant difference is found in educational funding and administration, in particular the fact that the majority of Canadian universities and colleges are mainly financed through public funds. Because of a dramatic increase in student enrolment, which began in the 1950s and 1960s and resulted in Canada becoming one of the countries with the highest numbers of post-secondary enrolments, financial and human resources were strained[1]. This situation became critical during the 1980s and 1990s, a period marked by difficult economic conditions, budget cut-backs, and lay-offs. Consequences of these conditions were large lecture classes and reduced or no contact between students and professors, a problem which was exacerbated by the fact that universities placed greater emphasis on research than on teaching[2]. As a result interest in the first-year experience arose at a much slower pace in Canadian universities and colleges, and University 101 type seminars based on the University of South Carolina model were adopted in only three Canadian Universities: the University of Prince Edward Island, the University of Manitoba and the University of Guelph, which began offering first-year seminars in the late 1980s and early 1990s. The majority of studies spurred by high student drop-out rates during the first college year in Canada began appearing in the 1990s and interest in the subject has not waned.

Indeed, student retention and the first-year experience continue to preoccupy administrators and educators in Canadian post-secondary institutions (Chapman et al., 1997; Kinder et al., 2006; ACCC and Human Resources and Social Development Canada, 2007). However, the vast majority of studies and articles related to Canadian post-secondary institutions focus on first-year experience seminars and provide little insight into information literacy and/or library initiatives. Of significance is the 1997 publication by The National Resource Center for The Freshman Year Experience and Students in Transition (Chapman et al., 1997) documenting programs and 
services offered to first-year students in Canadian universities and colleges, many of which have meanwhile been cancelled or modified from their original versions.

A more recent Canadian study of first-year experience programs, entitled University 101 Task Force Report (Kinder et al., 2006), was completed at Ryerson University in Toronto in 2006. This study surveyed 42 Canadian universities and identified 81 percent offering a short-term success seminar and 38 percent offering a "University 101" type term course. Of the 52 community colleges surveyed, 94 percent offer short-term success seminars and 39 percent offer “University 101” type courses.

\section{Library programs in Canadian post-secondary institutions}

While publications on the first-year experience in Canadian colleges and universities do not specifically address library involvement, a number of studies exist that examine information literacy and library programs offered in Canadian post-secondary institutions. Heidi Julien, Associate Professor at the School of Library and Information Studies at the University of Alberta, undertook and published several nationwide surveys on information literacy instruction in Canadian postsecondary institutions (Julien, 2000, 2005; Julien and Leckie, 1997). However, these studies focused on information literacy instruction in general and not on instruction aimed primarily at first-year students. In her 2005 paper, Julien presented a longitudinal study of 190 academic libraries in Canada (152 English-language and 47 French-language institutions), which, among others, found that 78.4 percent of the survey respondents were targeting first-year students. Unfortunately, the study does not provide any information as to the type and requirements of library courses given to the students. A search of academic library web sites in Canada carried out by the author reveals that only a few Canadian institutions offering library courses require them for specific academic programs (University of Lethbridge, 2006) or offer them as an elective. Furthermore, instead of a credit, some universities issue a certificate of participation (Brock University, 2006; Laurentian University, 2006), which may or may not appear on the student transcript.

The most common methods of delivery are, however, unstructured, in the form of library tours (in person and online), drop-in workshops, and course specific workshops upon demand by course instructors. Only a few post-secondary institutions also offer library instruction in the form of credit-based library courses[3] (elective and mandatory), as part of first-year seminars, or as a component of academic courses and summer programs. We present below an analysis of each of these modes of delivery.

\section{First-year seminars with library components}

First-year seminars can provide excellent opportunities for academic libraries to teach information literacy to new students. Indeed, a significant number of first-year seminars include library components in varying formats. In the late 1990s Chapman et al. (1997) found that 38 percent of Canadian universities that responded to their survey offered University 101 type seminars. The 2006 Ryerson University 101 Task Force obtained similar results even though their survey did not include francophone institutions.

Library components of first-year seminars differ from university to university depending on the institutions' needs and financial situations. They may simply consist of a library tour and an 
introduction to online databases, they can be delivered in the form of tutorials or in-class workshops, or they can be structured as a combination of both. In some instances, the library is involved in the design of these first-year seminars. Library involvement in the design of these courses ensures an effective representation of the information literacy module, as is the case with the "Ways of Knowing” program at the University of Windsor (University of Windsor, 2007).

Library tours/introduction to databases. This format of delivery is more common in orientationtype first-year experience seminars. A typical example is the " $\mathrm{U}$ of $\mathrm{C} \mathrm{101"} \mathrm{module} \mathrm{at} \mathrm{the}$ University of Calgary (University of Calgary, 2006). "U of C 101" is a mandatory, three-day orientation for first-year students held during the first week of September. The library component, entitled "Using libraries in the digital age" includes a library tour and an introduction to online databases.

Tutorials and/or in-class workshops. Tutorials and in-class workshops are the most frequently encountered formats in Canadian universities and colleges offering University 101 type term courses. For instance, the University of Prince Edward Island offers three different versions of first-year experience seminars - one is a distance education course - with either online or inclass library instruction. The two courses "University 100" and "University 103" include two or three library sessions during regular class time taught by a librarian (Johnston, 2007). These types of library tutorials/workshops given as part of an introductory course rank highly in student appreciation. For example, according to a survey carried out in 1991, "Improved library/research skills" ranked first among the "top twelve benefits of the course" (Chapman et al., 1997).

The University of Manitoba, offers the credit course ARTS 0111, based on "University 101" at the University of South Carolina. ARTS 0111, formerly "University 099.111," is a three-credit, elective seminar, which is taken by approximately 35 percent of first-year students. The seminar is a collaborative effort between four university departments, namely: the ARTS 0111 Course Director, Libraries, Student Advocacy, and Academic Computing and Networking (Tittenberger et al., 2006).

The library component of ARTS 0111, which used to be in the form of workshops, now consists of mostly online tutorials and some in-class sessions upon demand (Braaksma, 2007). The tutorials include four "eTools" sessions dealing with the fundamentals and tools for the improvement of research and writing skills. Evaluation is carried out on-line through a WebCt quiz, and results are incorporated into the final course mark. The "eTools" component accounts for 5 percent of the total course mark (Tittenberger et al., 2006).

In addition to providing library instruction within the framework of ARTS 0111, the University of Manitoba Libraries are planning to formally incorporate information literacy components into the academic curriculum of different programs (University of Manitoba Libraries, 2004).

Extensive library involvement. Extensive library involvement is ideally achieved by embedding librarians in first-year academic courses and by including them in curriculum development.

Several Canadian universities have recognized the advantages of strong collaborations between university librarians and teaching faculty and implemented collaborative programs in their institutions. For example, in 2006, the University of Windsor (2007), introduced "Ways of 
Knowing," a three-credit, elective seminar, which is held during the fall semester. The program involves five embedded librarians working with four groups of students, each on a continuous basis. The "Ways of Knowing" seminar is spearheaded by the information literacy librarian at the Leddy Library, Windsor University, who has directed the design team through the inception of the module to its introduction and implementation. The University of Windsor is now in the process of expanding the program to target a larger number of departments, starting in the fall of 2008 with the History Department (Bolton, 2008).

Teaching faculty and academic librarians at Ryerson University in Toronto have been involved in a similar venture by collaborating in the development and delivery of a mandatory first-year university preparation course: “ACS 102 Learning and Development Strategies.” This course has been offered since 2006 to first-year students in the Faculty of Arts (Social Science Division). A study quantifying the impact of this course on students has documented very positive outcomes. The study, based on statistics of pre- and post-tests, has shown that the percentage of students who passed the information literacy skills increased from 29 percent to 85 percent by the end of the course (Reed et al. 2007).

\section{Library course for credit (mandatory/elective)}

Credit-based library courses for first-year students appear to be the least popular formats. According to Julien (2000), less than 9 percent of Canadian post-secondary institutions offered this type of library instruction in 2000. The University of Winnipeg Library (2006) lists 40 "Information Literacy Credit Courses in Canadian Colleges and Universities" on their web site. A follow-up of the list by the author revealed that the number of credit-bearing information literacy courses has declined to about 21 courses by 2008, with the majority of these courses intended for students in second-year and above as, for example, at the University of Alberta, Augustana Campus (2008; Goebel and Neff, 2007; Neff, 2007).

The number of credit-based library courses for first-year students is decreasing continuously as educators and librarians come to realize the shortcomings of library credit courses. From a pedagogical point of view these courses are not very effective because they tend to be too general and are disconnected from academic programs, lacking the level of detail and specificity that would make them useful to the students. Elective library courses, on the other hand, are usually not well attended since they are not required for credit and since students in first year feel that they are not needed given that first-year students in most disciplines are not required to conduct in-depth research.

Among the few universities still offering credit-based information literacy courses for first-year students are: Athabasca University (2008), the University of Lethbridge (2006), and Douglas College (2007). Athabasca University features an elective three-credit course, "Information Systems 200," which is offered online. The University of Lethbridge offers "Library Science 2000: Library Research and Information Literacy,” a three-credit semester course, which is mandatory for BASc students but open to students in other disciplines. Douglas College in B.C. introduces new students to information literacy and research skills through an elective one and a half credit course, "LIBR 1111," which is taught during the first seven weeks of the semester. 
Some universities, such as Brock University, provide certificates in lieu of an academic credit. In September 2005, Brock University (2006) introduced “Info Skills PLUS,” a non-compulsory program for first-year students offered jointly through James A. Gibson Library, Career Services and the Student Development Centre. The program includes a series of seven workshops designed to enhance skills in information-related tasks. Undergraduate students who complete two core workshops and three electives receive an InfoSkills PLUS certificate and have their participation recorded on their Experience Skills Record. Students may participate in one or all workshops; however, the organizers stress the importance of information literacy by recommending very strongly "that SMART Start Library and Advanced Information Skills be completed before any other workshops."

\section{Component of academic course}

The most frequently encountered models of instruction are course-related (Jacobson and Mark, 2000; Boyd-Byrnes and McDermott, 2006.) However, these are not necessarily the most effective methods given that library instruction is frequently limited to only one session, in which the librarian teaches students how to use the catalogue and online databases.

Nonetheless, a substantial number of Canadian universities embed information literacy into some of their academic courses, most frequently into first year English courses as for example at Concordia University College of Alberta (Toews-Neufeldt, 2006), Trinity Western University (Badke, 2006) and The University British Columbia (2008). The University British Columbia Library is planning to embed information literacy in all first-year courses in most disciplines (Whitehead et al., 2002). At present The University of British Columbia Library is offering online tutorials for several academic courses.

Trent University integrated its online Library Skills Program tutorial into a large number of academic courses. During the 2006 academic year fourteen first-year courses and eight secondyear courses included the library tutorial. In order to ensure student participation, this implementation includes a request from the information services librarian at the Trent University Library asking course instructors to assign a mark - usually 5 percent of the total mark - to the library component (Luyben, 2007).

\section{Summer programs}

Courses/seminars. A few Canadian universities schedule their first-year seminars or information literacy/library programs during the summer. Generally universities and colleges provide short library orientation sessions as part of their summer pre-orientation for new students.

Trent University (2008) is the only university to offer a first-year experience seminar during the summer. "University Prep 101" is a non-credit summer preparation course offered to all new students in an online environment through the Academic Skills Centre. Library orientations and tests, which are offered online through the Library Skills Program web site in collaboration with the library, are an important part of the course (Eves, 2006). The library component is offered through the Library Skills Program web site (Trent University, 2007), which is accessible to all Trent students and mandatory for some courses. The Library Skills Program consists of online interactive slide shows on various library related topics which students can view at their own leisure. The tutorials cover subjects such as effective searching of the library's catalogue, 
databases, and internet. Student assessment is achieved by means of an online test which is graded immediately upon submission.

The University of Toronto (2007) offers a two-day intensive course on library research, report writing, and presenting at university level as part of their Summer Learning Institute. Because of the impact of this program, University of Toronto librarians, Fran Sardone and Saira Mall, were honoured with the CACULS's AGM award in 2006 (Canadian Library Association, 2006) for their initiative and efforts to introduce and implement this program.

The Emily Carr Institute of Art and Design (2007) organizes a month-long summer transition program for high school students, entitled "Summer Institute for Teens: The Pre-College Experience.” The program includes a library tutorial designed by a reference librarian (Ramen, 2007).

Common summer reading. Common summer reading programs can serve as a springboard for academic libraries to introduce new students to their facilities and services and to teach information literacy skills. The National Resource Center for the First-year Experience and Students in Transition, University of South Carolina (2002) lists about 92 American colleges and universities on their web site. The purpose of a common reading project is to bring "people closer as a community by creating common ground for discussion” (Ferguson, 2006, p. 8). The program involves several departments and faculties as well as the library in a collaborative effort to ease the transition for first-year students. Small group discussions are often supplemented with library research, involving library orientation and workshops (Ferguson, 2006, p. 9).

Consequently, students become familiar with library facilities and resources before they enter into their first year at the university.

In Canada common summer reading programs are not as popular as in the USA. Encouraged by the apparent success in American colleges and universities, some Canadian post-secondary institutions adopted this program, only to abandon it after the first or second summer due to lack of interest from students. The University of Western Ontario is not planning to repeat their summer reading program given that out of the 30 students who signed up in 2006 only five participated (Duncan, 2007). Other universities that were considering common summer reading programs never went beyond the planning stages as for example Brandon University (Sarbit, 2007) and the University of Victoria (Doyle, 2006).

The University of Guelph has been initially successful with their summer reading programs. Since its introduction in the late 1990s the program underwent various transformations and was last offered in 2006 under the title "Fiction Slam" (Kaufman, 2006). Unfortunately, "Fiction Slam" recently encountered the same fate as other programs of its kind and has been struck from the agenda of summer program offerings at the University of Guelph (Tersigni, 2007).

\section{Online library tutorials}

The inclusion of a library component into FYE programs can cause new challenges for academic libraries, particularly those belonging to big universities and serving large student populations. Organizing and teaching course-embedded information literacy requires a significant number of librarians, which is a particular challenge in Canadian post-secondary institutions, where budget 
cuts have been a common occurrence. Consequently, many universities and colleges in Canada are in favor and/or offer online tours and tutorials in different formats, even though opinions about their effectiveness diverge to a great extent (e.g. Churkovich and Oughtred, 2002; Adler, 2003; Jacobson and Mark, 2000).

Online tutorials can be either interactive or read-only in PDF or PPT format. Unfortunately, the completion of these tutorials is usually not mandatory and frequently they are too generic and do not target specific course content. Examples of self-guided online interactive tutorials, which may or may not be required by instructors of academic courses, can be found among others at the York University Library (2008), Concordia University Libraries (2008), Trent University (2007) as well as at The University of British Columbia (2008).

\section{Conclusion}

In this paper we present a survey of library instructional services for first-year students currently in use at Canadian academic libraries. The results of our study reveal that while the type of information literacy programs offered in Canadian post-secondary institutions are similar to those available in their American counter parts, there is a distinct difference in the frequency and distribution of program types in Canada. Credit courses are the least popular, while interest in course-specific library instruction appears to be on the rise. A significant difference between both countries is found in the availability of common summer reading programs with library components, which are almost non-existent in Canada. Similarly, first-year experience seminars based on the University of South Carolina model are offered in only three Canadian universities. Even though, this study identified a mix of in-class and online programs, there is a general trend towards online information literacy instruction in Canadian universities and colleges. This might be explained by the infrastructure, administration, funding, and size of student population of post-secondary institutions in Canada. However, further surveys that include a systematic analysis of the relative impact of in-class and on-line programs would be required to shed additional light on the role Canadian academic libraries play within the context of the first-year experience.

\section{Notes}

1. Since 1987 the number of students has increased by nearly 50 percent.

2. A detailed description of the Canadian experience can be found in Chapman et al. (1997). 3. In 2000 Julien found less than 9 percent of postsecondary institutions offering credit-based information literacy courses and 36 percent using computer-assisted library instruction.

\section{References}

ACCC and Human Resources and Social Development Canada (2007), Pan-Canadian Study of First Year College Students - Report 1 Student Characteristics and the College Experience August 2007, available at:

www.hrsdc.gc.ca/en/publications_resources/learning_policy/sp_787_08_07e/page02.shtml (accessed April 16, 2008), . 
Adler, R. (2003), "The librarian in the trench: the workaday impact of information literacy", Portal, Vol. 3 No.3, pp.447-58.

Athabasca University (2008), Information Systems 200, available at: www.athabascau.ca/courses/infs/200/ (accessed April 18, 2008), .

Badke, B. (2006), personal communication, November 9, .

Bolton, T. (2008), personal communication, April 30, .

Boyd-Byrnes, M.K., McDermott, D. (2006), "Reaching first year college students: current practices in instructional programs", Public Services Quarterly, Vol. 2 No.4, pp.1-22.

Braaksma, B. (2007), personal communication, May 4, .

Britnell, J., Schulman, D., Arooz, S., Cappadocia, F., Carr-Locke, J., Coppack, P., Fine, C., Gillis, A., Kinder, D., Little, D., Reed, M., Smith, C., Sulymko, T., Thorpe, J. (2002), The Task Force on Student Success and Retention: Final Report, Ryerson University, Toronto, .

Brock University (2006), InfoSkills PLUS, available at: www.brocku.ca/library/infoskills.htm (accessed April 18, 2008), .

Canadian Library Association (2006), CLA Press Release, available at: www.cla.ca/awards/2006\%20-\%20CACUL.pdf (accessed April 20, 2008), .

Chapman, J., Gilbert, S., Dietsche, P., Gardner, J., Grayson, P. (1997), From Best Intentions to Best Practices: The First-Year Experience in Canadian Postsecondary Education, National Resource Center for The Freshman Year Experience and Students in Transition, University of South Carolina, Columbia, SC, .

Churkovich, M., Oughtred, C. (2002), "Can an online tutorial pass the test for library instruction? An evaluation and comparison of library skills instruction methods for first year students at Deakin University", Australian Academic \& Research Libraries, Vol. 33 No.1, pp.25-38.

Concordia University Libraries (2008), InfoResearch 101, available at: http://juno.concordia.ca/help/tutorial/\# (accessed April 30, 2008), .

Douglas College (2007), Library: Research Skills, available at: www.douglas.bc.ca/calhtm/courses/clibr.html (accessed April 18, 2008), .

Doyle, S. (2006), personal communication, November 17, .

Duncan, L.G. (2007), personal communication, February 19, .

Emily Carr Institute of Art and Design (2007), Summer Institute for Teens: The Pre-college Experience, available at: www.eciad.ca/studies/cs/summer/teens (accessed April 18, 2008), . 
Eves, E.S. (2006), personal communication, November 14, .

Ferguson, M. (2006), "Creating common ground: common reading and the first year of college", Peer Review, Vol. 8 No.3, pp.8.

Goebel, N.E., Neff, P.J. (2007), "Information literacy at Augustana: a programmatic approach", Communications in Information Literacy, available at:

www.comminfolit.org/index.php/cil/search/authors/view?firstName=Paul\&middleName=J.\&last Name=Neff\&affiliation= Augustana\%20Campus\%20-\%20University\%20of\%20Alberta (accessed May 28, 2007), Vol. 1 No.1, pp.6-15.

(2007), in Hardesty, L. (Eds), The Role of the Library in the First College Year, National Resource Center for the First-year Experience and Students in Transition, University of South Carolina, Columbia, SC, Monograph No. 45, .

Jacobson, T.E., Mark, B.L. (2000), "Separating wheat from chafe: helping first-year students become information savvy", The Journal of General Education, Vol. 49 No.4, pp.256-78.

Johnston, V. (2007), personal communication, January 15, .

Julien, H. (2000), "Information literacy instruction in Canadian academic libraries: longitudinal trends and international comparisons", College \& Research Libraries, Vol. 61 No.6, pp.510-23.

Julien, H. (2005), "A longitudinal analysis of information literacy instruction in Canadian academic libraries", Canadian Journal of Information \& Library Sciences, Vol. 29 No.3, pp.289313.

Julien, H., Boon, S. (2003), "Information literacy in Canada's academic libraries", Feliciter, Vol. 49 No.6, pp.305-7.

Julien, H., Boon, S. (2004), "Assessing instructional outcomes in Canadian academic libraries", Library \& Information Science Research, Vol. 26 No.2, pp.121-39.

Julien, H., Leckie, G.J. (1997), "Bibliographic instruction trends in Canadian academic libraries", Canadian Journal of Information \& Library Sciences, Vol. 22 No.2, pp.1-15.

Kaufman, J. (2006), personal communication, November 17, .

Kinder, D., Reed, M., Gillis, A., Arooz, S., Carr-Locke, J. (2006), University 101 Task Force Report, Ryerson University, Toronto, .

Laurentian University (2006), Library Instruction, available at: www.laurentian.ca/library/libraryinstruction_e.php (accessed September 19, 2006), .

Luyben, J. (2007), personal communication, April 23, . 
National Resource Center for the First-year Experience and Students in Transition, University of South Carolina (2002), Institutions Reporting First-year Summer Reading Programs, available at: http://nrc.fye.sc.edu/resources/reading/read01.php (accessed April 18, 2008), .

Neff, P.J. (2007), personal communication, May 24, .

Ramen, M. (2007), personal communication, May 28, .

Reed, M., Kinder, D., Farnum, C. (2007), "Collaboration between librarians and teaching faculty to teach information literacy at one Ontario university: experiences and outcomes", Journal of Information Literacy, available at: http://ojs.lboro.ac.uk/ojs/index.php/JIL/article/view/RA-V1I3-2007-3/31(accessed April 30, 2008), Vol. 1 No.3, .

Sarbit, B. (2007), personal communication, January 23, .

Tersigni, P. (2007), personal communication, June 5, .

Tittenberger, P., McLean, C., Braaksma, B. (2006), Moving Online with Etools, available at: www.umanitoba.ca/academic_support/ltc/resources/brownbag/etools_mar06.ppt (accessed April 12, 2007), Vol. mar06.

Toews-Neufeldt, L. (2006), personal communication, November 10, .

Trent University (2007), Library Skills Program, available at: www.trentu.ca/admin/library/help/skills/info/index.html (accessed April 18, 2008), .

Trent University (2008), University Prep 101 - Summer 2008, available at: www.trentu.ca/academicskills/uprep.php (accessed April 18, 2008), .

University of Alberta - Augustana Campus (2007), Augustana Information Literacy Courses 2007-2008, available at:

www.augustana.ca/files/group/600/IL\%20course\%20offering\%20for\%202007-2008\%20\%20March\%2013\%202007.pdf (accessed April 18, 2008), .

(The) University of British Columbia Library (2008), Instruction Centre, available at: www.library.ubc.ca/home/instruct/welcome.html (accessed April 19, 2008), .

University of Calgary (2006), U of C 101: Student Orientation, available at: www.ucalgary.ca/uofc101/main/newstudents.html (accessed May 2, 2007), .

University of Lethbridge (2006), Library Instruction/Tours, available at: www.uleth.ca/lib/services/display.asp?PageID=61\#courses (accessed April 30, 2008), .

University of Manitoba Libraries (2004), 2003-2004 Annual Report, available at: www.umanitoba.ca/libraries/about/AnnualReport_2003_04.pdf (accessed April 18, 2008), . 
University of Toronto (2007), Summer Learning Institutes, available at: www.utsc.utoronto.ca/ $\sim$ tlsweb/students/SLI_RW\&P/default.htm (accessed June 7, 2007), .

University of Windsor (2007), Ways of Knowing, available at:

http://apps.medialab.uwindsor.ca/cfl/reflexions/volume01/issue01/Ways_of_Knowing.htm (accessed April 18, 2008), .

University of Winnipeg Library (2006), Information Literacy Credit Courses in Canadian Colleges and Universities, available at:

http://library.uwinnipeg.ca/about/accessservices/il/cdn_credit.cfm?instituion=University (accessed April 16, 2008), .

Whitehead, M., Adam, S., Neame, S., Rosseel, T., Taylor, S. (2002), Report of the Task Group on Information Literacy, Task Group 2.1, The University of British Columbia Library, Vancouver, BC, available at: http://weblogs.elearning.ubc.ca/ric/archives/2.01FinalReportNovember22-2002_1.doc (accessed May 29, 2007), .

York University Library (2008), Library Research Roadmap, available at: www.library.yorku.ca/roadmap (accessed April 18, 2008), .

\section{Further Reading}

University of Prince Edward Island (2007), University 100, available at:

www.upei.ca/registrarsoffice/html/2_uni100.html (accessed January 12, 2007), .

University of Toronto Libraries (2007), 2007 UTL Staff Conference, available at: www.library.utoronto.ca/event/staffconference/index.html (accessed June 8, 2007), . 